\title{
Linarite from the Ag-Pb ore deposit at Kletné near Suchdol nad Odrou (Jeseníky Culm, Vítkov Highlands)
}

\author{
Vladimír Hrazdil, Stanislav Houzar, Jiří Sejkora, \\ Šárka Koníčková \& Lenka Jarošová
}

\begin{abstract}
Linarite from the Ag-Pb ore deposit at Kletné near Suchdol nad Odrou (Jeseníky Culm, Vítkov Highlands).
\end{abstract} - Acta Mus. Siles. Sci. Natur., 65: 88-96, 2016.

\begin{abstract}
Linarite, $\mathrm{PbCu}^{2+}\left(\mathrm{SO}_{4}\right)(\mathrm{OH})_{2}$, and associated minerals were studied at new locality near Kletné, where they occur in dump material of historic $\mathrm{Ag}-\mathrm{Pb}$ mines exploited during the $16^{\text {th }}$ century. Linarite forms thin blue coatings and tiny dark blue crystals $(<1 \mathrm{~mm}$ in size) in small cavities, in assemblage with cerussite, brochantite and supergene copper sulfides. Mineral was identified by chemical analyses (electron microprobe), Raman spectroscopy and powder X-ray diffraction analysis. Chemical composition of the studied linarite can be expressed by empirical formula $\mathrm{Pb}_{0.98} \mathrm{Cu}_{1.06}\left(\mathrm{SO}_{4}\right)_{\Sigma 0.96}(\mathrm{OH})_{2.15}$ and its refined unit-cell parameters are: $a=9.6944(3), b=5.6499(2), c=$ 4.6846(1) $\AA, \beta=102.669(3)^{\circ}$ and $V=250.50(1) \AA^{3}$. Linarite formed together with other supergene minerals in the oxidation zone of the deposit by weathering of $\mathrm{Pb}$ - and $\mathrm{Cu}$-sulphides.
\end{abstract}

Key words: linarite, brochantite, chemical composition, Raman spectrum, powder X-ray diffraction data, unit-cell parameters, Jeseníky Culm, historical mine dumps, Czech Republic.

\section{Introduction}

Linarite, $\mathrm{PbCu}^{2+}\left(\mathrm{SO}_{4}\right)(\mathrm{OH})_{2}$, is a relatively common secondary mineral typically present in weathering (gossan) zones of base-metal deposits. In the Moravian-Silesian region, linarite is known particularly from rich occurrences in Zlaté Hory, Silesia (Fojt 1959). It also was sparsely found in Moravia - at Nová Ves u Rýmařova (Kocourková \& Losos 2008), Koroužné near Bystřice nad Pernštejnem (Houzar \& Malý 2002), Hrubá Voda near Olomouc (Novotný et al. 2005) and Helenín near Jihlava (Pauliš et al. 2013). Its occurrence is expected to be more frequent but it is often confused with the more abundantly present azurite.

A new occurrence of linarite accompanied by other supergene minerals was found at the small $\mathrm{Ag}-\mathrm{Pb}$ ore deposit in Kletné. Only limited information on mining of Ag-Pb ores at Kletné is available in literature. As for older publications, only a brief summary of mining sites including a list of identified minerals Krut'a (1962 a, b); also detailed historical study (Drkal 1964) and topographic and historic information (Novák 1978) were published. A new, popular scientific overview of mining in Vítkov Highlands was published by Klika (2008). In this paper, we provide description of newly discovered mineral assemblages with linarite and characterization of their minerals.

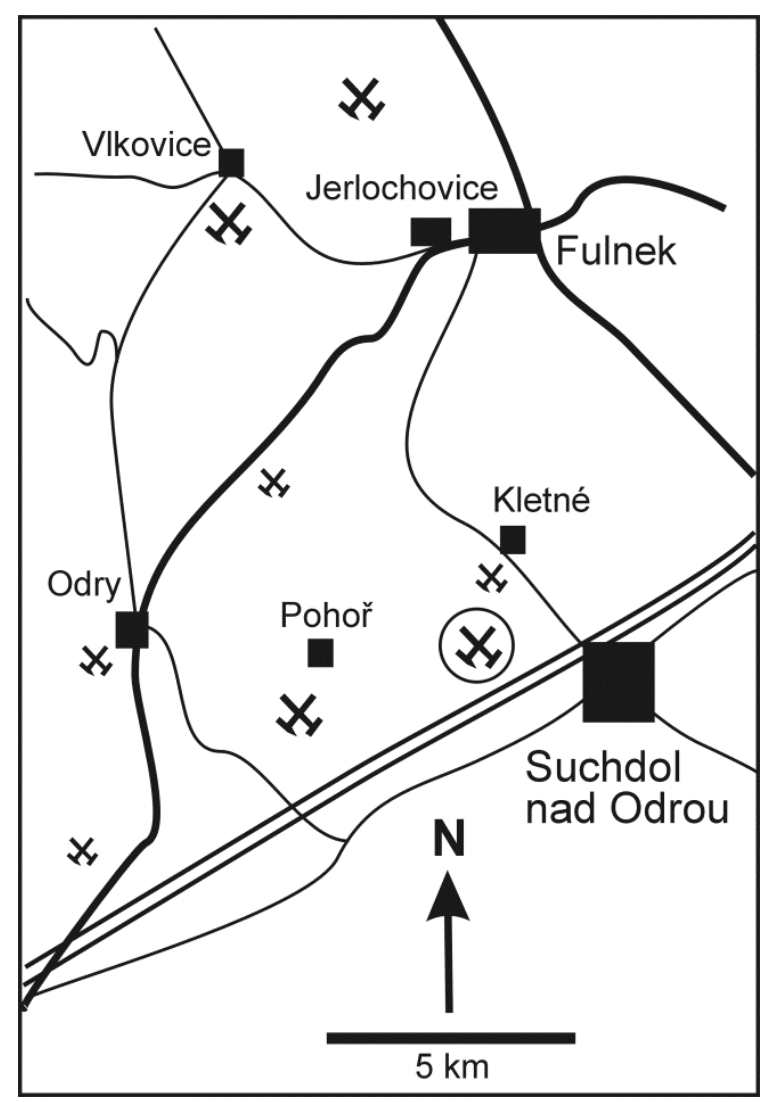

Fig 1: Topographic sketch of historical mines in Kletné vicinity with the studied location marked with circle. 


\section{Overview of historical mining in Kletné area}

Historical mining of $\mathrm{Ag}-\mathrm{Pb}$ ores in the Kletné region is proven in only a few historical sources - some information is probably found under mining in "Pohoř Mountains at Fulnek manor" - (Fig 1). Based on these reports, the oldest work may have been performed there as early as in the late Middle Ages before the $14^{\text {th }}$ century at the time of the Opava mint operation (Klika 2008). The first (and mostly sporadic) written sources available originated in the $16^{\text {th }}$ century. In 1515 silver and lead were mined by Odry townsmen in "Pohor Forest". According to scarce written sources, in addition to new mining attempts, old mines were locally reopened between 1534 and 1589 (Novák 1978), e.g. in 1552 in "Pohoř Hills" including Kletné (Klötten, d'Elvert 1895). Mining is also mentioned in sources referring to cases from 1551 when Petr Oslar from Opava and Valentin Scheuspurger attempted mining near Kletné and from 1552 and 1568 stating the local name "Pod doly" (Drkal 1964). Krut'a (1962a) mentions "Nad doly" Kletné track from 1588. Since local mines were adjacent to mines in nearby Pohoř, historical reports are often unclear as to the topography; silver furnaces were allegedly built in Kletné and Pohoř (authors' remark: improbable). Other private miners operating on "Pohoř Hill" in 1747 (5 other locations) mined also close to Kletné (3 locations). In 1748, ore containing 1 - 2 "quints" of silver in a "cent" (approx. 80 $150 \mathrm{~g} / \mathrm{t}$ ) is reported from Pohoř and containing 3 "quints" of silver in a "cent" is reported close to Kletné (Krut'a 1962a, Drkal 1964). This yield of silver would be insignificant due to mining costs of the time. Existence of an old, almost $30 \mathrm{~m}$ long adit near Kletné leading in the eastern direction to a big mining shaft in the same year is described in Novák (1978).

In 1771, both a private company and the government tried to reopen local mines. The old Pohoř and Kletné workings were inspected by mine surveyor Pappa but mining was not commenced. It was concluded for Kletné (as well as Pohoř) that the local mines are very small and their ore deposits - lead and copper ores with low silver content and gold traces are exhausted (Drkal 1964). Exploratory and mining activities were also conducted in the near vicinity later, e.g. in 1795 and 1807 - 1817. It is not clear if they related to the aforementioned mines near Kletné (Krut’a 1962a, Novák 1978, Klika 2008). The last attempts by Fulnek notary public J. Ludwig in end $19^{\text {th }}$ century were unsuccessful (Drkal 1964), too.

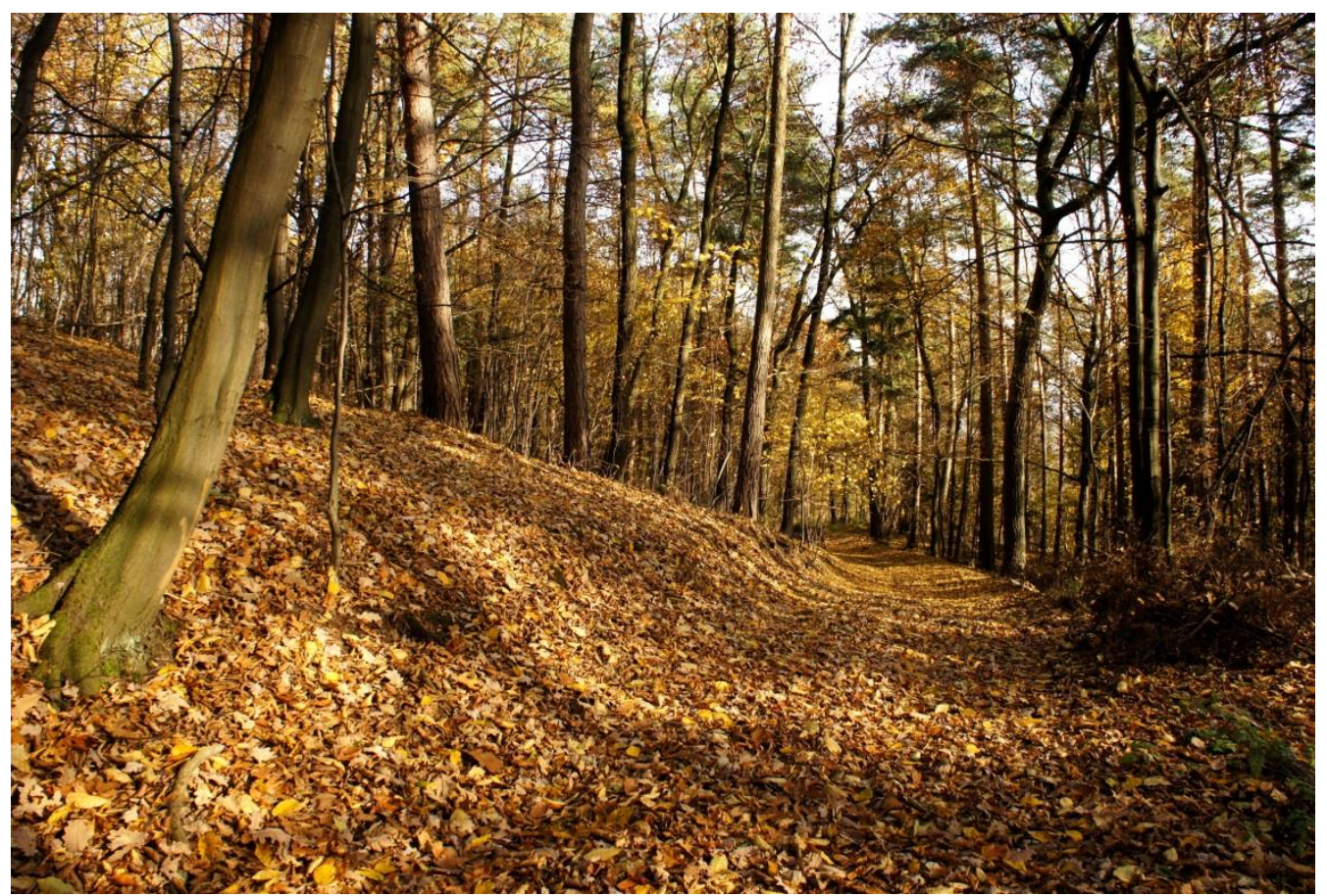

Fig 2: Linarite locality - large mine dumps near Kletné. Photo by L. Jarošová, November 2014. 


\section{Location characteristics and mineralization}

The studied locality is situated about $700 \mathrm{~m} \mathrm{SSW}$ of Kletné at the blue-marked tourist path to Pohoř (GPS: $49^{\circ} 39^{\prime} 51.506^{\prime \prime} \mathrm{N} ; 17^{\circ} 54^{\prime} 6,708^{\prime \prime} \mathrm{E}$ ). There are large flat mine dumps above the road from Kletné to Pohoř (Fig 2), as well as minor cuts and surface depressions from the mining, with several conspicuous remains of caved adit and shaft entrances. The historical works follow approximately NW-SE direction (330 ) up to $300 \mathrm{~m}$ distance and minor prospecting works were also performed in close vicinity (Fig 3).

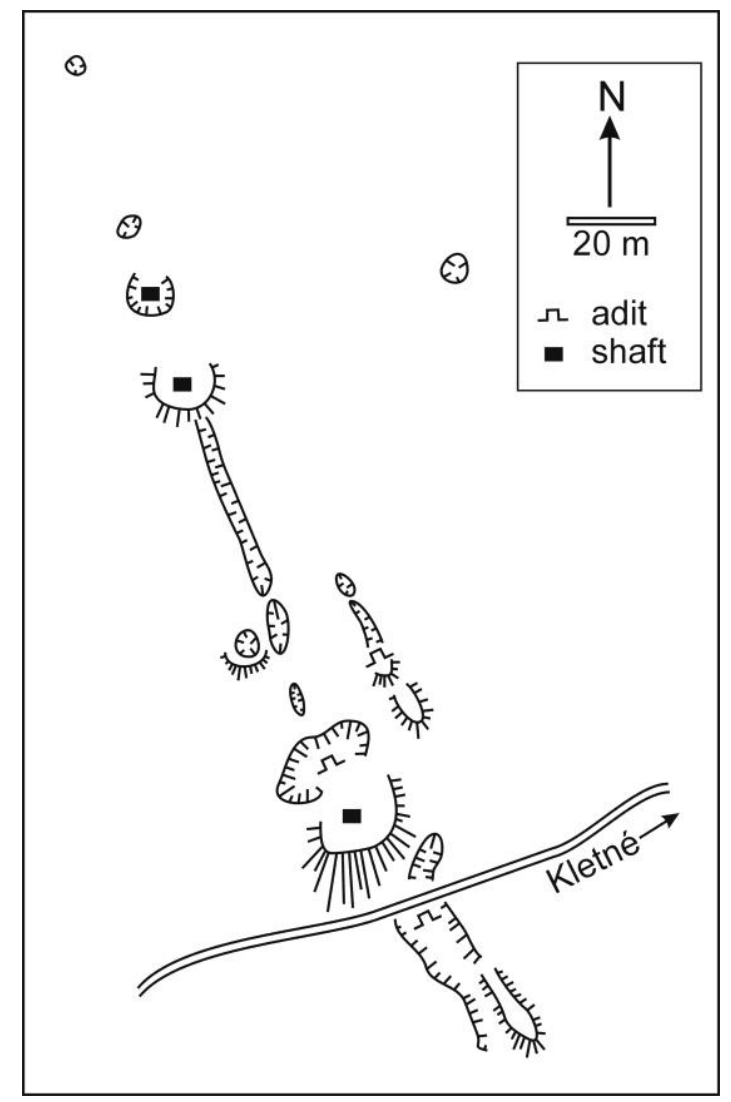

Fig 3: Remains of historical mining of Pb ores near to Kletné (adapted from Novák 1978).

Based on the contents on the mine dumps, the main carriers of Ag- $\mathrm{Pb}$ mineralization were quartz-carbonate and carbonate "veins" or tectonic breccias formed by crushed rocks of clayey-sandy character with fragments of altered rocks of Hradec-Kyjovice formation in the Jeseníky culm (Viséan). The ore mineralization was represented by massive galena aggregates and grains with a low share of pyrite and chalcopyrite. Intense altered, carbonatized sandstones (greywackes) breccias with fine disseminated sulphides and supergene $\mathrm{Fe}-\mathrm{Cu}-\mathrm{Pb}$ were also identified (Drkal 1964, Novák 1978). The main mined ore was galenite (Drkal 1964, Novák 1978). As for the other minerals, Krut'a (1962b) lists pyrite, chalcopyrite, ankerite, calcite and quartz, and cerussite, malachite, rare azurite, unique pure sulphur and recent chalcanthite as supergene minerals.

The ore material on the mine dumps is strongly altered and limonitized. Massive galena is lined with thin grey-white cerussite coatings. Small galena grains remained only as relics in porous and massive aggregates composed of anglesite, cerussite and quartz. Cerussite forms also small tabular crystals of up to $3 \mathrm{~mm}$ size in cavities and on cracks. Thin blue and green coats of supergene copper minerals limited in size are often present. They were identified as linarite and brochantite (this paper). More sporadic findings include supergene $\mathrm{Cu}$ sulphides and sub-recent blue covellite with metallic lustre on cracks $(<0.5 \mathrm{~mm})$, and black-grey chalcocite (Fig 4). 


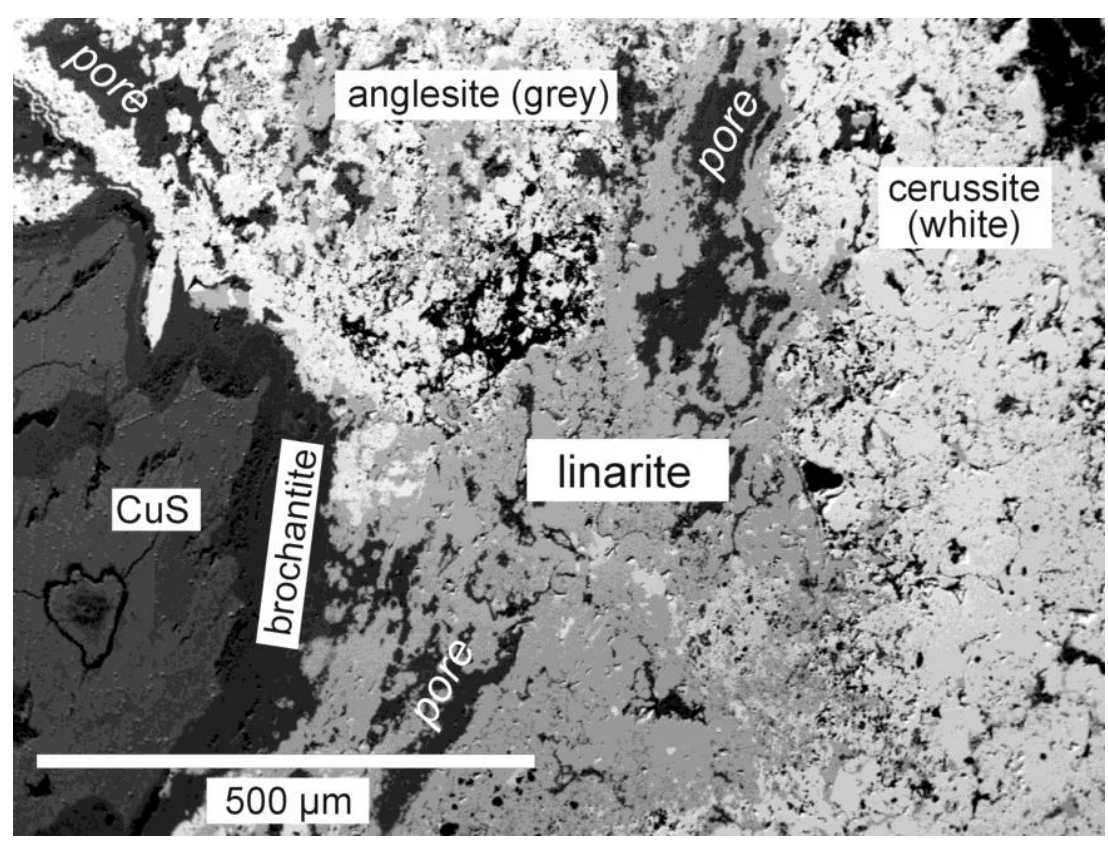

Fig 4: Supergene assemblage of $\mathrm{Cu}-\mathrm{Pb}-\mathrm{S}-\mathrm{CO}_{3}$ minerals from Kletné deposit (BSE image).

\section{Methods of research}

A chemical composition was carried out at a joint electron microscopy and microanalysis facility of the Department of Geological Sciences of Faculty of Science of Masaryk University and the Czech Geological Survey (analyst R. Škoda) using a Cameca SX 100 electron microprobe. Measurements were recorded under the following conditions: wave-dispersive mode, $15 \mathrm{kV}$ voltage, $10 \mathrm{nA}, 20 \mathrm{nA}$ current, $8 \mu \mathrm{m}$ beam size. The following standards were applied in linarite and brochantite analysis: lammerite $(\mathrm{Cu} K \alpha$, AsL $\alpha)$, vanadinite $(\mathrm{PbM} \alpha, \mathrm{Cl} \mathrm{K} \alpha), \mathrm{SrSO}_{4}(\mathrm{~S} \mathrm{~K} \alpha)$, gahnite $(\mathrm{Zn} \mathrm{K} \alpha)$, spessartine $(\mathrm{Mn} \mathrm{K} \alpha)$, almandine (Fe $\left.\mathrm{K} \alpha\right), \mathrm{Mn}_{2} \mathrm{SiO}_{4}(\mathrm{Mn} \mathrm{K} \alpha)$, $\mathrm{Mg}_{2} \mathrm{SiO}_{4}(\mathrm{Mg} \mathrm{K} \alpha)$, sanidine ( $\left.\mathrm{Si} \mathrm{K} \alpha, \mathrm{Al} \mathrm{K} \alpha, \mathrm{K} \mathrm{K} \alpha\right)$, fluorapatite $(\mathrm{P} \mathrm{K} \alpha, \mathrm{Ca} \mathrm{K} \alpha)$ and topas $(\mathrm{F} \mathrm{K} \alpha)$. Elements not listed in the table were below detection limits $(0.04-0.1$ wt. \%). Raw data were coordinated using X-phi correction (Merlet 1994).

Raman spectrum of linarite (performed on uncoated surface of sample) was acquired using of a Horiba LabRAM HR Evolution spectrometer (Department of Geological Sciences of Masaryk University, analyst Š. Koníčková). This dispersive, edge filter-based system was equipped with an Olympus BX-series optical microscope, a diffraction grating with 600 grooves per millimetre, and Peltier-cooled, Si-based charge-coupled device (CCD) detector. Raman spectra were excited with $532 \mathrm{~nm}$ emission of a diode laser ( $3 \mathrm{~mW}$ at the sample surface). With Olympus 50x LWD objective (0.5 numerical aperture) and the system being operated in the confocal mode, the lateral resolution was $\sim 1 \mu \mathrm{m}$. Wavenumber calibration was done using the Rayleigh line and Si lamp emissions. The evaluation was made using LabSpec 6 and PeakFit 4 software. Measurement conditions: aperture - hole: 400 , slit: 100 , filter: $25-50 \%$, range: $80-2000 \mathrm{~cm}^{-1}$.

X-ray powder diffraction pattern of linarite was obtained from hand-picked samples using a Bruker D8 Advance diffractometer equipped with solid-state 1D LynxEye detector using $\mathrm{Cu} K_{\alpha}$ radiation and operating at 40 $\mathrm{kV}$ and $40 \mathrm{~mA}$ (National Museum, Prague). In order to minimize the background, the powdered sample was placed on the surface of a flat silicon wafer from acetone suspension. The powder pattern was collected using Bragg-Brentano geometry in the range $4-70^{\circ} 2 \theta$, in $0.01^{\circ}$ steps with a counting time of 8 sec per step (total duration of the experiments was about 10 hours). The positions and intensities of diffractions were found and refined using Pearson VII profile-shape function of ZDS program package (Ondruš 1993) and the unit-cell parameters were refined by the least-squares program by Burnham (1962).

\section{Linarite characteristics}

\section{LINARITE $\mathrm{PbCu}^{2+}\left(\mathrm{SO}_{4}\right)(\mathrm{OH})_{2}$}

Linarite typically forms discrete, light-blue coats and narrow veinlets in weathered porous ore formed by quartz, cerussite, anglesite and fine-grained Fe-dolomite and calcite, with galena and pyrite relics. Little blue crystalline aggregates in small cavities with cerussite and quartz do not occur frequently. Dark blue tabular and bar crystals of up to $1 \mathrm{~mm}$ size occur sporadically. They are associated with older cerussite and anglesite (Fig 5a, b). 


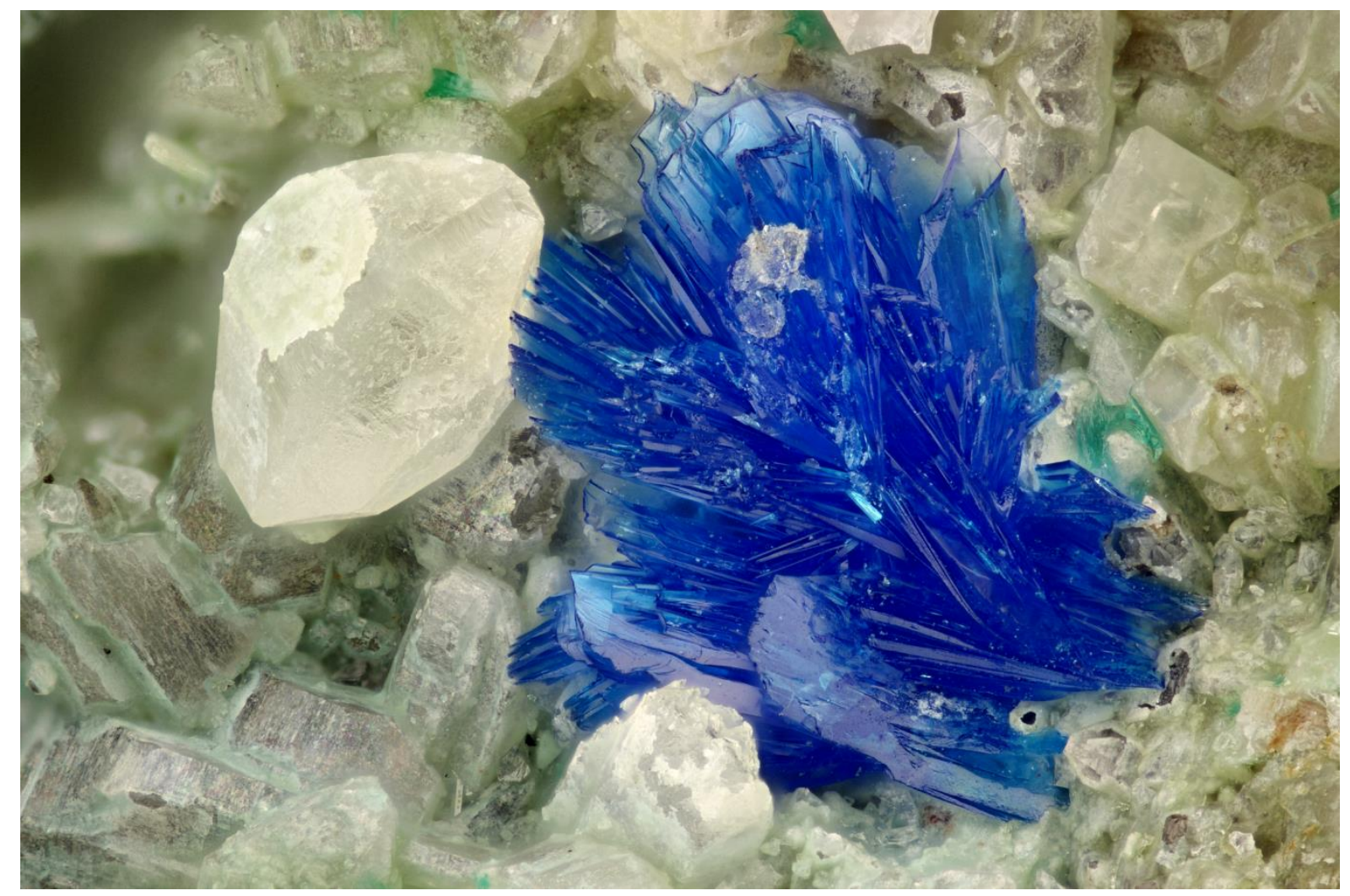

Fig 5a: Tabular blue linarite with white cerussite and tiny green brochantite aggregates (4 mm width). Photo by R. Kummer.

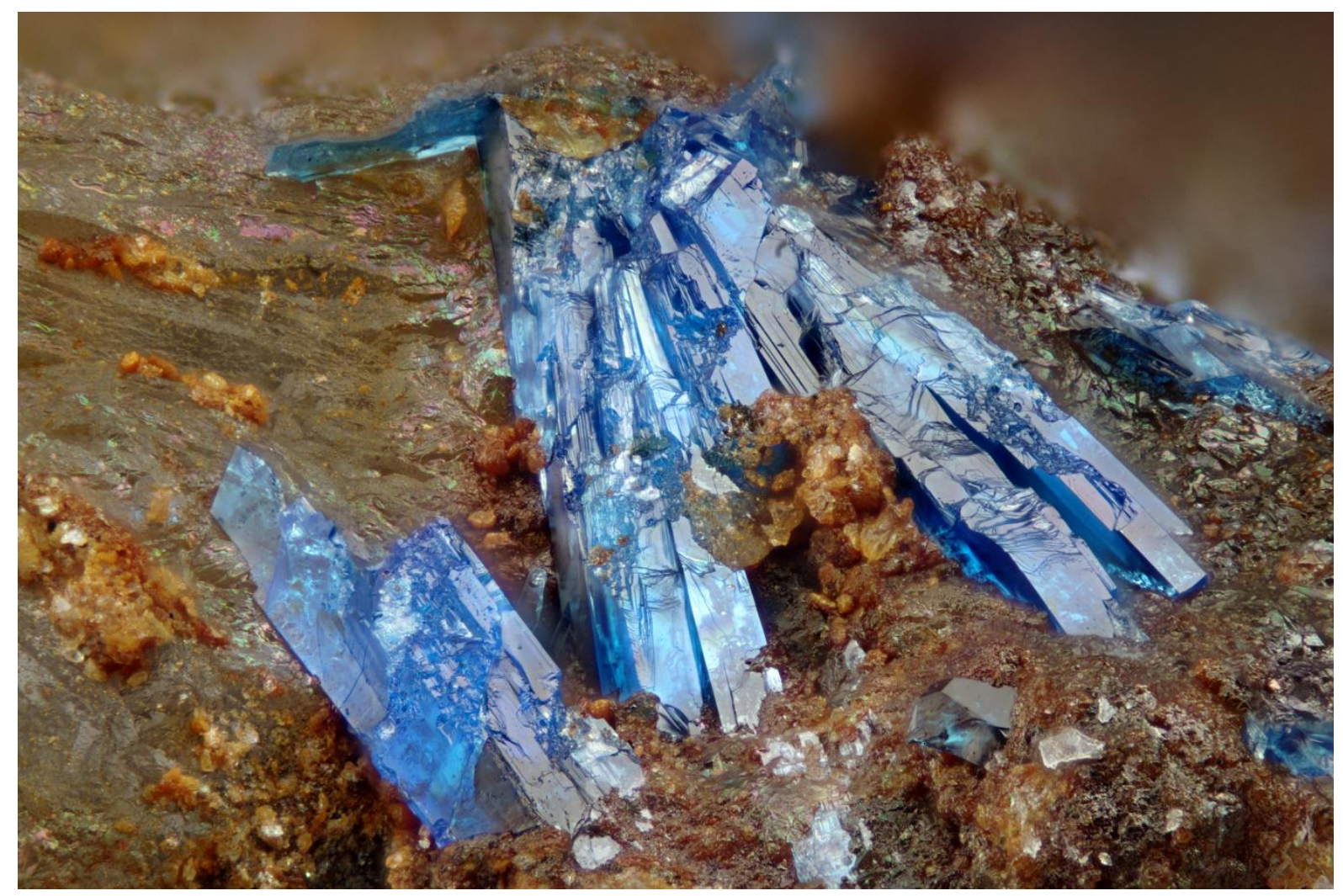

Fig 5b: Prismatic linarite crystals with quartz and iron oxi/hydroxides (4 mm width). Photo by R. Kummer. 
In thin section, linarite is transparent, pleochroic ( $\mathrm{X}$ - pale blue, $\mathrm{Y}-$ blue, $\mathrm{Z}$ - intensive blue), and form parallel prismatic orms. The identified chemical composition of linarite (Tab 1 ) is very close to its ideal formula; other elements typical for secondary mineralization (As, $\mathrm{Ba}, \mathrm{Cl}, \mathrm{F}, \mathrm{Fe}, \mathrm{K}, \mathrm{Mn}, \mathrm{Na}, \mathrm{P}, \mathrm{Zn}$ ) were not found even in minor amounts (above detection limit of the method). The chemical composition of linarite (mean of 8 point analyses) can be expressed on the basis of 3 cation apfu by empirical formula $\mathrm{Pb}_{0.98} \mathrm{Cu}_{1.06}\left(\mathrm{SO}_{4}\right)_{\Sigma 0.96}(\mathrm{OH})_{2.15}$

Tab 1: Chemical composition of linarite and brochantite from Kletné (wt. \%).

\begin{tabular}{lrrrrrrrr}
\hline & \multicolumn{3}{c}{ linarite } & \multicolumn{1}{c}{ brochantite } \\
\hline & \multicolumn{1}{c}{ mean } & \multicolumn{1}{c}{1} & \multicolumn{1}{c}{3} & \multicolumn{1}{c}{4} & mean & \multicolumn{1}{c}{1} & \multicolumn{1}{c}{2} \\
\hline $\mathrm{PbO}$ & 55.32 & 55.54 & 54.83 & 55.44 & 55.46 & 1.58 & 1.07 & 2.08 \\
$\mathrm{CuO}$ & 21.29 & 21.10 & 21.69 & 21.19 & 21.18 & 69.62 & 69.73 & 69.51 \\
$\mathrm{SO}_{3}$ & 19.51 & 19.64 & 19.25 & 19.37 & 19.76 & 17.70 & 17.96 & 17.43 \\
$\mathrm{H}_{2} \mathrm{O}^{*}$ & 4.90 & 4.84 & 5.01 & 4.91 & 4.83 & 11.91 & 11.84 & 11.99 \\
\hline total & 101.01 & 101.12 & 100.78 & 100.91 & 101.23 & 100.80 & 100.60 & 101.01 \\
\hline $\mathrm{Pb}$ & 0.979 & 0.983 & 0.971 & 0.985 & 0.979 & 0.032 & 0.022 & 0.042 \\
$\mathrm{Cu}$ & 1.058 & 1.048 & 1.078 & 1.056 & 1.049 & 3.966 & 3.964 & 3.969 \\
$\mathrm{~S}$ & 0.963 & 0.969 & 0.951 & 0.959 & 0.972 & 1.002 & 1.014 & 0.989 \\
$\mathrm{OH}$ & 2.150 & 2.123 & 2.199 & 2.161 & 2.112 & 5.992 & 5.944 & 6.046 \\
\hline
\end{tabular}

Coefficients of empirical formula were calculated on the basis of 3 apfu (linarite) or 5 apfu (brochantite); $\mathrm{H}_{2} \mathrm{O}^{*}$ contents calculated on the basis of charge balance.

The Raman spectrum of linarite from Kletné (Fig 6, Tab 2) is close to the spectrum of this mineral phase published by Buzgar et al. (2009) and spectra of samples R060130 and R120094 from RRUFF database. The most intense band at $965 \mathrm{~cm}^{-1}$ is related to the $v_{1}$ symmetric stretching mode of the sulphate group. Bending modes of the sulphate group were observed at $628,608\left(v_{4}\right)$ and 458, $433\left(v_{2}\right) \mathrm{cm}^{-1}$. Bands in the range of $1200-1000 \mathrm{~cm}^{-1}$ can be assigned to the $v_{3}$ antisymmetric stretching mode of the sulphate group; the band at 1053 $\mathrm{cm}^{-1}$ (not observed in published spectra) can be manifestation of symmetric stretching vibration of $\left(\mathrm{CO}_{3}\right)$ group of cerussite present as a microinclusion in the studied linarite. The other bands observed in linarite spectrum at 508 and $360 \mathrm{~cm}^{-1}$ are probably connected to vibration of $(\mathrm{OH})$ groups and $(\mathrm{Cu}, \mathrm{Pb})-\mathrm{OH}$ vibrations, respectively.

Tab 2: Tentative assignment of Raman spectrum of linarite from Kletné.

\begin{tabular}{ccc}
\hline this paper & Buzgar et al. (2009) & Tentative assignment \\
\hline 1138 & 1143 & $v_{3}$ antisymmetic stretching vibration of $\left(\mathrm{SO}_{4}\right)$ group \\
1053 & 1021 & \\
\hline 965 & 967 & $v_{1}$ symmetric stretching vibration of $\left(\mathrm{SO}_{4}\right)$ group \\
\hline & 819 & bending vibration of $(\mathrm{OH})$ group \\
\hline 628 & 634 & $v_{4}$ bending vibration of $\left(\mathrm{SO}_{4}\right)$ group \\
608 & 613 & \\
\hline 508 & 518 & vibration of $(\mathrm{OH})$ groups \\
\hline 458 & 465 & $v_{2}$ bending vibration of $\left(\mathrm{SO}_{4}\right)$ group \\
433 & 437 & \\
\hline 360 & 366 & M-OH vibration \\
\hline
\end{tabular}


Tab 3: X-ray powder diffraction data for linarite from Kletné.

\begin{tabular}{|c|c|c|c|c|c|c|c|c|c|c|c|}
\hline$h$ & $k$ & $l$ & $d_{\text {obs. }}$ & $I_{o b s .}$ & $d_{\text {calc. }}$ & $h$ & $k$ & $l$ & $d_{o b s .}$ & $I_{\text {obs. }}$ & $d_{\text {calc. }}$ \\
\hline 1 & 0 & 0 & 9.466 & 13.1 & 9.458 & 1 & 2 & -2 & 1.8025 & 5.5 & 1.8035 \\
\hline 1 & 1 & 0 & 4.850 & 10.6 & 4.850 & 2 & 1 & 2 & 1.8025 & 5.5 & 1.8024 \\
\hline 2 & 0 & 0 & 4.729 & 7.5 & 4.729 & 5 & 1 & -1 & 1.8025 & 5.5 & 1.8022 \\
\hline 0 & 0 & 1 & 4.571 & 0.5 & 4.573 & 5 & 1 & 0 & 1.7936 & 6.0 & 1.7938 \\
\hline 1 & 0 & -1 & 4.526 & 46.2 & 4.525 & 0 & 2 & 2 & 1.7776 & 2.0 & 1.7774 \\
\hline 1 & 0 & 1 & 3.807 & 2.5 & 3.803 & 4 & 1 & -2 & 1.7666 & 3.0 & 1.7670 \\
\hline 2 & 0 & -1 & 3.721 & 0.5 & 3.721 & 2 & 3 & 0 & 1.7497 & 1.0 & 1.7497 \\
\hline 2 & 1 & 0 & 3.627 & 9.0 & 3.626 & 0 & 3 & 1 & 1.7414 & 2.0 & 1.7414 \\
\hline 0 & 1 & 1 & 3.555 & 22.6 & 3.555 & 1 & 2 & 2 & 1.6951 & 0.5 & 1.6952 \\
\hline 1 & 1 & 1 & 3.153 & 100.0 & 3.155 & 1 & 3 & 1 & 1.6878 & 1.0 & 1.6877 \\
\hline 3 & 0 & 0 & 3.153 & 100.0 & 3.153 & 2 & 3 & -1 & 1.6803 & 1.5 & 1.6803 \\
\hline 2 & 1 & -1 & 3.108 & 14.1 & 3.107 & 3 & 2 & -2 & 1.6753 & 2.0 & 1.6753 \\
\hline 2 & 0 & 1 & 2.978 & 14.1 & 2.977 & 5 & 0 & -2 & 1.6455 & 2.5 & 1.6456 \\
\hline 3 & 0 & -1 & 2.912 & 0.5 & 2.911 & 5 & 0 & 1 & 1.6266 & 2.0 & 1.6266 \\
\hline 0 & 2 & 0 & 2.825 & 6.5 & 2.825 & 3 & 1 & 2 & 1.6138 & 2.0 & 1.6137 \\
\hline 3 & 1 & 0 & 2.753 & 0.7 & 2.753 & 4 & 2 & 1 & 1.5961 & 1.0 & 1.5961 \\
\hline 1 & 2 & 0 & 2.707 & 10.6 & 2.707 & 3 & 3 & -1 & 1.5814 & 2.0 & 1.5813 \\
\hline 3 & 1 & -1 & 2.588 & 11.6 & 2.588 & 2 & 2 & 2 & 1.5778 & 2.0 & 1.5776 \\
\hline 2 & 2 & 0 & 2.4250 & 2.0 & 2.4252 & 5 & 2 & -1 & 1.5778 & 2.0 & 1.5775 \\
\hline 0 & 2 & 1 & 2.4035 & 5.0 & 2.4034 & 6 & 0 & 0 & 1.5765 & 0.5 & 1.5764 \\
\hline 1 & 2 & -1 & 2.3972 & 0.5 & 2.3963 & 4 & 2 & -2 & 1.5537 & 0.5 & 1.5537 \\
\hline 3 & 0 & 1 & 2.3646 & 4.0 & 2.3647 & 6 & 1 & -1 & 1.5418 & 2.0 & 1.5417 \\
\hline 1 & 0 & -2 & 2.3435 & 2.0 & 2.3432 & 0 & 0 & 3 & 1.5245 & 3.5 & 1.5245 \\
\hline 4 & 0 & -1 & 2.3180 & 13.1 & 2.3181 & 3 & 0 & -3 & 1.5083 & 2.0 & 1.5082 \\
\hline 1 & 2 & 1 & 2.2678 & 5.5 & 2.2679 & 1 & 1 & -3 & 1.5036 & 1.5 & 1.5035 \\
\hline 2 & 0 & -2 & 2.2624 & 9.5 & 2.2623 & 2 & 1 & -3 & 1.4984 & 1.0 & 1.4983 \\
\hline 2 & 2 & -1 & 2.2501 & 1.0 & 2.2499 & 4 & 0 & 2 & 1.4887 & 3.0 & 1.4887 \\
\hline 3 & 1 & 1 & 2.1813 & 10.1 & 2.1814 & 3 & 3 & 1 & 1.4732 & 1.0 & 1.4732 \\
\hline 1 & 1 & -2 & 2.1645 & 7.5 & 2.1644 & 4 & 3 & 0 & 1.4732 & 1.0 & 1.4732 \\
\hline 4 & 1 & -1 & 2.1446 & 1.0 & 2.1446 & 1 & 3 & -2 & 1.4678 & 0.5 & 1.4679 \\
\hline 0 & 1 & 2 & 2.1194 & 13.1 & 2.1197 & 0 & 3 & 2 & 1.4537 & 0.5 & 1.4537 \\
\hline 1 & 0 & 2 & 2.1194 & 13.1 & 2.1191 & 3 & 2 & 2 & 1.4463 & 0.5 & 1.4464 \\
\hline 3 & 2 & 0 & 2.1039 & 5.5 & 2.1039 & 5 & 2 & -2 & 1.4218 & 0.5 & 1.4219 \\
\hline 2 & 2 & 1 & 2.0494 & 1.0 & 2.0493 & 0 & 4 & 0 & 1.4125 & 1.5 & 1.4125 \\
\hline 3 & 2 & -1 & 2.0275 & 3.0 & 2.0274 & 1 & 1 & 3 & 1.4096 & 2.0 & 1.4097 \\
\hline 3 & 1 & -2 & 1.9525 & 1.0 & 1.9524 & 4 & 1 & -3 & 1.3883 & 2.0 & 1.3884 \\
\hline 2 & 0 & 2 & 1.9017 & 1.0 & 1.9017 & 7 & 0 & -1 & 1.3806 & 0.5 & 1.3807 \\
\hline 1 & 3 & 0 & 1.8471 & 1.5 & 1.8471 & 6 & 2 & 0 & 1.3763 & 1.0 & 1.3766 \\
\hline 4 & 1 & 1 & 1.8302 & 7.0 & 1.8302 & 1 & 2 & -3 & 1.3653 & 0.5 & 1.3655 \\
\hline 3 & 2 & 1 & 1.8133 & 7.5 & 1.8133 & 6 & 1 & 1 & 1.3578 & 1.0 & 1.3578 \\
\hline 4 & 2 & 0 & 1.8133 & 7.5 & 1.8132 & & & & & & \\
\hline
\end{tabular}

The X-ray powder diffraction pattern of linarite (Tab 3) corresponds very well to the published data for this mineral and the theoretical pattern of linarite calculated from the crystal structure data (Effenberger 1987). The refined unit-cell parameters of linarite from Kletné are compared to the published data in Tab 4. 
Tab 4: Unit-cell parameters of linarite (for monoclinic space group $P 2_{1} / m$ ).

\begin{tabular}{|c|c|c|c|c|c|c|}
\hline & & $a[\AA ̊]$ & $b[\AA ̊]]$ & c [̊̊] & $\beta\left[^{0}\right]$ & $V\left[\AA^{3}\right]$ \\
\hline Kletné & this paper & $9.6944(3)$ & $5.6499(2)$ & $4.6876(1)$ & $102.669(3)$ & $250.50(1)$ \\
\hline Leadhills & Effenberger (1987) & $9.701(2)$ & $5.650(2)$ & $4.690(2)$ & $102.65(2)$ & 250.82 \\
\hline Leadhills & Schofield et al . (2009) & $9.682(2)$ & $5.646(1)$ & $4.683(6)$ & $102.66(1)$ & $249.80(6)$ \\
\hline Dolní Kramolín & Pauliš et al. (2012) & $9.6886(9)$ & $5.6459(4)$ & $4.6846(5)$ & $102.66(1)$ & $250.00(4)$ \\
\hline Helenín & Pauliš et al. (2013) & $9.690(2)$ & $5.6440(8)$ & $4.6846(9)$ & $102.64(2)$ & $250.00(8)$ \\
\hline
\end{tabular}

Linarite is sporadically accompanied by tiny green coatings $\left(<10 \mathrm{~mm}^{2}\right)$ of finely crystalline brochantite with chemical composition close to the ideal formula $\mathrm{Cu}_{4}\left(\mathrm{SO}_{4}\right)(\mathrm{OH})_{6}$ (Tab 1). In addition to dominant $\mathrm{Cu}$ and $\mathrm{S}$, traces of $\mathrm{Pb}(0.74-2.08$ wt. \%) were also indentified. Its chemical composition corresponds to the empirical formula $\left(\mathrm{Cu}_{3.97} \mathrm{~Pb}_{0.03}\right)_{\Sigma 4.00}\left(\mathrm{SO}_{4}\right)_{\Sigma 1.00}(\mathrm{OH})_{5.99}$ on the basis of 5 apfu of cations.

Locally abundant reddish-grey coatings of apparently older iron-oxi/hydroxides associated with linarite and brochantite were identified (Fig 5a, b).

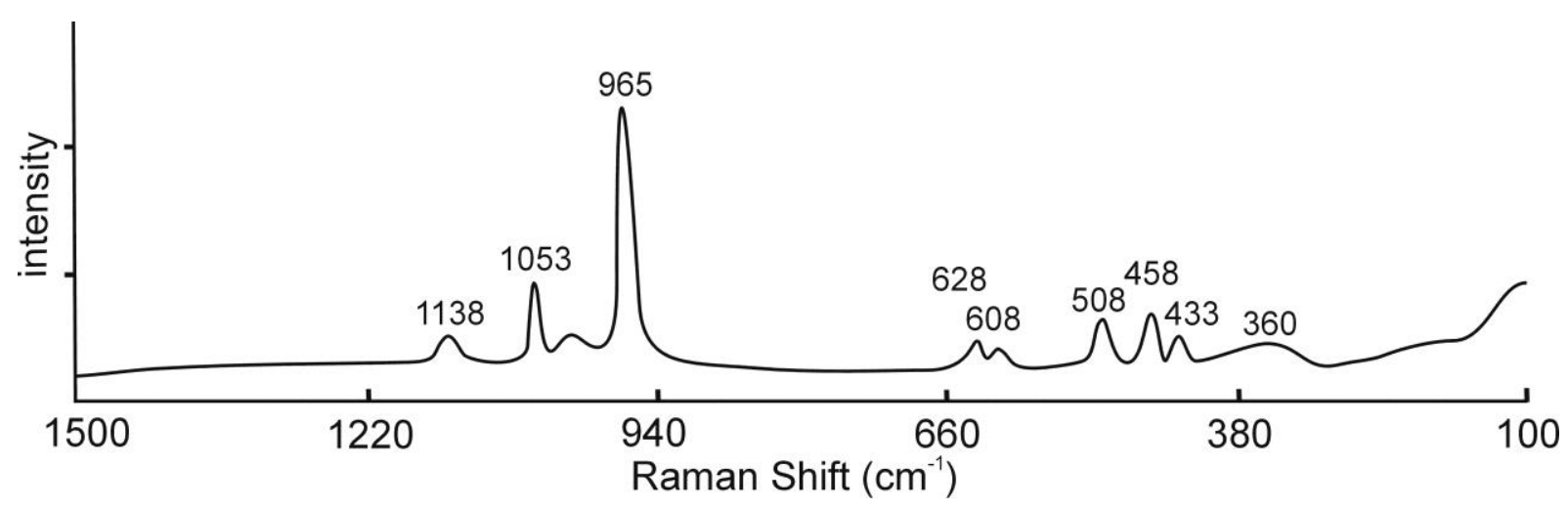

Fig 6: Raman spectrum of linarite from Kletné.

\section{Discussion and conclusions}

The mineral assemblages of linarite suggest that it formed as a secondary mineral. Relics of primary ore strongly affected by in-situ supergene processes were identified at mine dumps of historical Ag,Pb-mines near Kletné. Massive galena aggregates with surfaces coated with cerussite, filling cracks in shales and greywackes together with carbonates (dolomite, $\mathrm{Fe}$ dolomite, calcite; cf. Zimák et al. 2002), are found sporadically. Exogenous processes resulted in weathering of the primary ore material to a white-grey, slightly crystalline mixture of anglesite and cerussite with relics of galena, pyrite, and chalcopyrite, and rare supergene $\mathrm{Cu}$ sulphides. Blue linarite coatings occur frequently in some areas with linarite forming tiny crystals in small cavities. Linarite was identified on the basis of chemical composition, Raman spectroscopy as well as powder X-ray data. Adjacent rocks are strongly altered, silicified and carbonatized, with frequent supergene iron oxi/hydroxide (,limonite") coatings and, in some areas, with green brochantite coatings; a typical massive "gossan" goethite was not found. Linarite ranks among minerals younger than cerussite and anglesite; their texture is similar as in Hrubá Voda where pseudomorphs of cerussite formed in some areas as well (Novotný et al. 2005). Malachite and azurite mentioned by Krut'a (1962b) were not identified.

The strong alteration of $\mathrm{Pb}$ and $\mathrm{Cu}$ sulphides and supergene cerussite predominance over galena in the dump material suggest that the mining works likely did not reach large depths 
below the oxidized zone of the deposit; different situation (non-oxidized dump material) can be observed in nearby Pohoř mines ("Gold Pit" neighbourhood) where fresh ore was mined directly from hydrothermal veins. Recent weathering at mine dumps also contributed to the origin of some of the supergene minerals but its effects within the whole assemblage of supergene minerals are difficult to estimate. It is likely to be partly represented by the "limonite" mentioned above as well as sporadic coatings and small crystals of blue chalcanthite (Krut'a 1962b) in some areas.

Acknowledgements: This article appears through financial support provided to the Moravian Museum by the Ministry of Culture of the Czech Republic as part of its long-term conceptual development programme for research institutions (MK000094862 - V. Hrazdil, S. Houzar), dtto for Silesian Museum (MK000100595) - internal grants Nos. IGS201503/2015 and IGS201602/2016 (L. Jarošová) and DKRVO 2016/02 (National Museum 00023272 - J. Sejkora). We thank to Radek Kummer for high-quality photos and Jan Cempírek for text corrections.

\section{References}

B urnham C.W. (1962): Lattice constant refinement. - Carnegie Inst. Wash., Yearb. 61: 132-135.

Buzgar N., Buzatu A. \& Sanislav V. (2009): The Raman study on certain sulfates. - Analele Stiintifice Ale Universitatii „Al. I. Cuza“ IASI Geologie, 55 (1): 5-22.

d'Elvert Ch. (1866): Zur Geschichte des Bergbaues und Hüttenwesens in Mähren und Oest. Schlesien. - Schriften der stat.hist. Section der mähr.-schles. Gesellschaft, Bd. 15, Brünn, 438 p;

Drkal S. (1964): Dolování na Fulnecku. - Vlastivěda Ostravského kraje, Vítkovsko, 8: 2-6, Ostrava.

Effenberger H. (1987): Crystal structure and chemical formula of schmiederite $\mathrm{Pb}_{2} \mathrm{Cu}_{2}(\mathrm{OH})_{4}\left(\mathrm{SeO}_{3}\right)\left(\mathrm{SeO}_{4}\right)$, with a comparison to linarite $\mathrm{PbCu}(\mathrm{OH})_{2}\left(\mathrm{SO}_{4}\right)$. - Mineral. Petrol. 36: 3-12.

Fojt B. (1959): Linarit ze Zlatých Hor ve Slezsku. - Čas. Morav. muz., Vědy př́rodní 44: 53-56.

Houzar S. \& Malý K. (2002): Přehled mineralogie, ložiskových poměrů a historie štěpánovského rudního revíru na západní Moravě. - Acta Mus. Morav., Sci. geol. 87: 5-59.

Klika R. (2008): O těžbě stř́bronosných rud ve Vítkovské vrchovině. - Minerál 16(6): 513-521.

Kocourková E. \& Losos Z. (2008): Supergenní minerály na ložisku Pb-Zn rud Nová Ves u Rýmařova. - Čas. Slez. Muz. Opava (A) 57:193-210.

Krut'a T. (1962a): Přehled mineralogických a geologických poměrů v okrese Nový Jičín s přihlédnutím k výskytům rud a nerostných surovin. - Vlastivědný sborník Novojičínsko 5: 12-14.

- (1962b): Přehled mineralogických a geologických poměrů v okrese Nový Jičín s přihlédnutím k výskytům rud a nerostných surovin. - Vlastivědný sborník Novojičínsko 6: 7-11.

Merlet C. (1994): An accurate Computer Correction Program for Quantitative Electron Probe Microanalyses. Microchimica Acta 114/115: 363-376

Novák J. (1978): Topografie dolování a výskytu rud v rudním revíru Fulnek-Odry. - Sborník Geologického průzkumu Ostrava 17: 65-77.

Novotný P., Sejkora J. \& Pauliš P. (2005): Nové nálezy supergenních minerálů v horninách spodního karbonu (kulmu) v okolí Olomouce. - Bull. mineral.-petrolog. Odd. Nár. Muz. (Praha) 13: 172-176.

Ondruš P. (1993): A computer program for analysis of X-ray powder diffraction patterns. - Materials Sci. Forum, EPDIC-2, Enchede 133-136: 297-300.

Pauliš P., Jebavá I. \& Vlk J. (2012): Linarit z Dolního Kramolína (rudní revír Michalovy Hory, Česká republika). - Bull. mineral.-petrolog. Odd. Nár. Muz. (Praha) 20(1): 83-86.

Pauliš P., Kopecký S. \& Jebavá I. (2013): Supergenní asociace s linaritem z Helenína v jihlavském rudním revíru. Bull. mineral.-petrolog. Odd. Nár. Muz. (Praha) 21(1): 52-56.

Schofield P.F., Wilson C.C., Knight K.S. \& Kirk C.A. (2009): Proton location and hydrogen bonding in the hydrous lead copper sulfates linarite $\mathrm{PbCu}\left(\mathrm{SO}_{4}\right)(\mathrm{OH})_{2}$, and caledonite $\mathrm{Pb}_{5} \mathrm{Cu}_{2}\left(\mathrm{SO}_{4}\right)_{3} \mathrm{CO}_{3}(\mathrm{OH})_{6}$. - Can. Mineral. 47: 649-662.

Zimák J., Losos Z., Novotný P., Dobeš P. \& Hladíková J. (2002): Study of vein carbonates and notes to the genesis of hydrothermal mineralisation in the Moravo-Silesian Culm. - J. Czech geol. soc. 47(3-4): 111-122.

Internet source: Databáze Raman spekter, RTG - difrakce a chemických dat pro minerály (online). Dostupné z: http://rruff.info/linarite/display=default/R060130. (cit. 15. 2. 2016).

Authors' addresses: Vladimír Hrazdil \& Stanislav Houzar, Department of Mineralogy and Petrography, Moravian Museum, Zelný trh 6, CZ-65937 Brno, Czech Republic. E-mails: vhrazdil@mzm.cz; shouzar@mzm.cz. Jiří Sejkora, Department of Mineralogy and Petrology, National Museum, Cirkusová 1740, CZ-193 00 Praha, Czech Republic. E-mail: jiri_sejkora@nm.cz.

Šárka Koníčková, Department of Geological Sciences, Masaryk University, Kotlářská 2, CZ-61137 Brno, Czech Republic. E-mail: konickova@tezebni-unie.cz.

Lenka Jarošová, Silesian Museum, Tyršova 1, CZ-74601 Opava, Czech Republic.

E-mail: geologie@szm.cz. 